Katarzyna Laskowska

\title{
735 lat zwalczania i... Rzecz o korupcji w Rosji
}

Keywords: Russia, corruption

\section{Summary}

The phenomenon of corruption in Russia, shown in the historical perspective, is described here by changes of legislation in this matter throughout the ages. It is clearly seen that changes of legal regulation tried to penalize many new aspects of bribery and to increase of penalty. The attitude of the society, both Russian and Soviet, shows that legal regulations have been ignored not only by citizens, but also by the state's officers. The scale of corruption now and damages it causes is an evidence that there is no effective system of protection against these crimes in Russia.

Współczesna Rosja jest krajem, w którym korupcja osiąga niebywałe rozmiary. Transparency International plasuje ją wśród najbardziej skorumpowanych państw świata ${ }^{1}$. Stanowi ona poważny problem, zarówno o charakterze politycznym, gospodarczym, jak i społecznym.

Celem niniejszego opracowania jest ukazanie zjawiska korupcji w Rosji na przestrzeni wieków, głównie pod kątem ewolucji ustawodawstwa. Jak wskazuje tytuł publikacji, funkcjonowanie prawa antykorupcyjnego w Rosji ma długą historię. Matematyczne wyliczenie lat podejmowania trudu legislacyjnego wynika z uznania przez rosyjskich historyków daty 1274 r. jako roku przyjęcia pierwszej

1 Według T.I. w 2007 r. w skali 10-stopniowej (10 oznacza brak korupcji) Rosję oceniono na 2,3. Podobny poziom tego zjawiska w tym roku odnotowano także w Gambii, Indonezji, Togo. Zob. Я. И. Гилинский, Криминология. Теория, история, эмпирическая база, соииальный контроль, Санкт-Петербург 2009, s. 313. 
regulacji w tym zakresie i roku 2009 - jako granicznego dla rozważań. Na potrzeby opracowania dokonano symbolicznego podziału omawianych okresów. Za istotne w historii rozwoju korupcji uznano następujące etapy: 1274-1917, 1918-1991 i 1992-2009.

Podstawą analiz będą akty prawne obowiązujące we wskazanych okresach. Należy jednak zastrzec, że rozważania historycznoprawne do początków XX w., nie są oparte na źródłach pierwotnych. Natomiast analizy dotyczące ustawodawstwa XX-wiecznego (głównie kodeksów karnych) przeprowadzone będą już przy wykorzystaniu dostępnych aktów prawnych. W opracowaniu użyte zostaną także opracowania rosyjskich prawników i kryminologów.

Należy w tym miejscu przypomnieć, że „korupcja” jest określeniem funkcjonującym w Rosji zarówno w powszechnym użytku, jak i w prawie od niedawna. Przez wieki posługiwano się w niej przede wszystkim pojęciem „łapownictwo". W różnych okresach używano też innych słów na oznaczenie zjawiska. W związku z tym, by nie zatracić ducha prawa omawianych epok, zdecydowano się posługiwać ówcześnie obowiązującymi określeniami.

\section{Prawo rosyjskie wobec łapownictwa w okresie od XIII w. do $1917 \mathrm{r}$.}

Korzenie łapownictwa w Rosji sięgają kilka wieków wstecz, bowiem, jak podaje A. I. Kirpicznikow², już w XIII w., metropolita Kirył, opuszczając Kijów i udając się do Włodzimierza podczas podróży, głosił potrzebę zwalczania «мздоимства»", czarów i pijaństwa". Stąd też, gdy w 1262 r. arcybiskup Sawwa przysłał mu Кормчую книгу, będącą bizantyjskim zbiorem prawosławnych praw, Kirył rozszerzył go o przepis zabraniający przyjmowania $\mathcal{M} \partial \boldsymbol{b l}^{4}$ przez księży, diakonów i przeorów. Po soborze władymirskim od 1274 r. stał się on źródłem obowiązującego prawa rosyjskiej cerkwi. Można przyjąć, że rozpoczęła się wówczas era zwalczania łapownictwa w Rosji.

Jednakże od początku nie było to łatwe, gdyż legalnym przejawem zjawiska stało się tzw. кормление. Polegało ono na obowiązku utrzymywania urzędników państwowych (głównie wojewodów, namiestników prowincji) przez mieszkańców podległych im terytoriów ${ }^{5}$. Zatem za wykonywanie swych obowiązków urzędnik pobierał wynagrodzenie nie od kniazia (którego był przedstawicielem), a od społeczności lokalnej.

2 Я. И. Кирпичников, Российская коррупция, Санкт-Петербург 2004, s. 30.

3 Słowo „мздоимство” w tłumaczeniu na język polski oznacza „łapownictwo”.

4 Słowo „мзда” w tłumaczeniu na język polski oznacza „łapówkę”.

5 Я. И. Гилинский, ор. cit., s. 313.; К. Ф. Шергина, Коррупция в России и проблемы уголовноправового противодействия, „Следователь” 2008, nr 5, s. 53. 
Próby prawnego ograniczenia łapownictwa podjął się (w Судебникуzbiorze praw z 1497 r.) wielki kniaź moskiewski Iwan III, a także jego wnuk - Iwan Groźny. To za rządów tego ostatniego w Судебнику z 1550 r. zakazano przyjmowania łapówek przez sędziów. Przewidziano surowe kary pieniężne, biczowanie, więzienie, a nawet karę śmierci za „niesprawiedliwe (za łapówkę - przypis K. L.) osądzenie człowieka"6. W celu ograniczenia łapownictwa w 1555 r.7 lub w 1556 r. ${ }^{8}$ Iwan Groźny wydał ukaz uchylający кормление. Jednakże zanim zaczął on obowiązywać na całym terytorium podległym carowi, instytucja ta funkcjonowała jako sposób utrzymania urzędników w miastach. W celu ograniczenia możliwości bogacenia się wysokich urzędników i sędziów car ustanowił kadencyjność ich urzędów na 1 rok (wyjątkowo dla wojewodów - 2 lata) ${ }^{9}$. Kolejny krok podjęty przez Iwana Groźnego, zmierzający do ograniczenia łapownictwa w Rosji, stanowiła Судная грамота z 1561 r., przewidująca karę śmierci za przyjęcie łapówki przez urzędnika sądowego ${ }^{10}$.

Pomimo tak surowego prawa, łapownictwo w Rosji rozwijało się, powodując wzrost roli urzędników carskich, których działania cechowała dowolność, dobrowolność i niesprawiedliwość w podejmowaniu decyzji. Dlatego, jak podkreślają A.I. Kirpicznikow ${ }^{11}$ i A. I. Mizerij ${ }^{12}$, w 1648 r. nastąpił bunt narodowy przeciwko łapownictwu i łapownikom w tym kraju. Miał on, w ocenie A. I. Kirpicznikowa ${ }^{13}$, decydujący wpływ na uchwalenie w 1649 r. Соборного уложения ${ }^{14}$. Przewidziano w nim kary wobec nieuczciwych sędziów oraz wojewodów i bojarów ${ }^{15}$, którzy za łapówki zwalniali wybrane osoby z wojska. Odpowiedzialność ich regulowały odpowiednio art. 5 i art. 7 Уложения ${ }^{16}$.

Prawdziwa walka $\mathrm{z}$ łapownictwem w Rosji nastąpiła za panowania cara Piotra I. Jak podkreślają prawnicy, były to czasy zarówno rozkwitu zjawiska, jak i bezwzględnej z nim walki. W ramach porządkowania kraju car podjął się próby ustanowienia zakresu obowiązków urzędników i zasad powoływania ich na wysokie stanowiska. W związku z tym m.in. ustanowił 2-letnią kadencję wojewodów, która mogła być przedłużona tylko na podstawie pisemnego wnio-

${ }^{6}$ Я. И. Кирпичников, op. cit., s. 30-31.

${ }^{7}$ Jak podaje Я. И. Кирпичников, op. cit., s. 31.

${ }^{8}$ Jak podaje Я. И. Гилинский, op. cit., s. 313.

9 Я. И. Кирпичников, op. cit., s. 31.

10 А. И. Мизерий, История борьбь с коррупцией в России, http://www.unn.ru /pages/ issues/ vestnik/9999-0195_West_pravo_2001_2(4)/27.pdf.

11 Я. И. Кирпичников, ор. cit., s. 34.

12 А. И. Мизерий, ор. cit.

13 Я. И. Кирпичников, op. cit., s. 34.

${ }^{14}$ Szerzej w polskiej literaturze na temat rozwiązań zawartych w Cyдебнuкy zob.: I. Kwiatkowska, Prawo karne w kodyfikacji rosyjskiej 1649 roku, „Zeszyty Naukowe Uniwersytetu Jagiellońskiego DCLXXI . Prace prawnicze 1984", z.105.

15 Ibidem, s. 34.

16 А. И. Мизерий, ор. cit. 
sku społeczności lokalnej. Ukazem z 23.08.1713 r. Piotr I wprowadził odpowiedzialność zarówno za przyjmowanie, jak i wręczanie łapówek. Za popełnienie tych przestępstw przewidział kary cielesne, z karą śmierci włącznie. Ustanowił nagrodę dla donosiciela na skorumpowanego urzędnika. Był nią jego majątek, a w przypadku wysokiego urzędnika - nawet jego stanowisko ${ }^{17}$.

24.12.1714 r. Piotr I wydał ukaz przewidujący surowe kary za popełnienie przestępstw związanych $\mathrm{z}$ wykonywaniem obowiązków służbowych przez urzędnika państwowego. Wprowadził przepis penalizujący odpowiedzialność za pomocnictwo w popełnieniu tych nadużyć oraz za niepoinformowanie o popełnieniu przestępstwa przez inną osobę $e^{18}$. Donos w sprawach o łapownictwo stał się obowiązkiem prawnym.

Podejmowane przez cara wysiłki (szeroki zakres kryminalizacji, wysokie kary) nie przyniosły efektów w zwalczaniu łapownictwa w Rosji. Wręcz przeciwnie, zjawisko to przybrało na sile. Trzeba przyznać, że jest ono fenomenem w skali Rosji. Łapowników rosyjskich nie złamały bowiem surowe wyroki, publiczne ich wykonywanie czy konfiskowanie mienia. Chęć wzbogacenia się była znacznie silniejsza niż strach przed karą.

Należy przypomnieć, że do czasów Piotra I na określenie łapownictwa używano zamiennie 2 роје̨с́: мздоимство і лихоимство. Od reform Piotra I za мздоимство uznano przyjęcie łapówki za wykonywanie czynności przez urzędnika na rzecz petenta bez naruszenia prawa, a zа лихоимство - przyjęcie łapówki za wykonanie czynności z naruszeniem prawa ${ }^{19}$.

W następnych latach, w ramach reformy zarządzania krajem, car Aleksander I powołał ministerstwa i departamenty, których powstanie spowodowało wzrost biurokracji będącej podłożem łapownictwa. W kolejnym okresie, za panowania Mikołaja I, rozwojowi łapownictwa sprzyjały: brak kontroli aparatu urzędniczego, niskie jego morale oraz słabe wykształcenie, a także „produkowanie" dokumentacji i wieloszczeblowość jej obiegu ${ }^{20}$.

Ważnym krokiem w zwalczaniu zjawiska było przyjęcie w 1845 r. Уложения о наказаниях уголовных и исправительных ${ }^{21}$. W akcie tym w 13 artykułach przewidziano odpowiedzialność za nadużycia urzędników dokonywane w celu osiągnięcia korzyści majątkowej. Skryminalizowano w nich różne rodzaje, formy i sposoby uzyskiwania łapówki. Karę przewidziano zarówno za łapówkę będącą podziękowaniem, jak też za łapówkę będącą „podkupieniem” urzędnika. Spenalizowano wręczenie lub przyjęcie łapówki przez pośredników zarówno

\footnotetext{
${ }^{17}$ Ibidem.

${ }^{18}$ Ibidem.

${ }^{19}$ Ibidem.

${ }^{20}$ А. И. Годунов, Противодействие организованной преступности, Москва 2003, s. 331.

${ }^{21}$ W Polsce przyjęta nazwa aktu brzmi: „Kodeks kar głównych i poprawczych”.
} 
za wykonanie czynności, jak i za zaniechanie oraz za przyjęcie jej w wyniku szantażu ${ }^{22}$.

Należy zauważyć, że wszystkie wymienione regulacje miały charakter represyjny i zmierzały do ukarania sprawców. Potrzeby przeciwdziałania (prewencji w sensie pozytywnym) ówcześni ustawodawcy nie dostrzegali. Nastąpiło to dopiero w ukazie Об изыскании причин и представлению средств $\kappa$ искорению сей язвы z listopada 1862 r., w którym po raz pierwszy w historii Rosji postawiono pytania o podłoże rozwoju łapownictwa w tym kraju. Odpowiedzi na nie udzielił specjalnie powołany komitet, który jako przyczyny rozwoju tego zjawiska wskazał: niedoskonałość prawa, słabe zabezpieczenie finansowe urzędników oraz niewspółmierność przestępstwa i kary ${ }^{23}$. Trzeba też dodać, że na bezgraniczne łapownictwo w omawianym okresie wpłynął także brak należnej kontroli działalności aparatu urzędniczego ${ }^{24}$.

Dalsze kroki prawne wobec łapownictwa zostały podjęte w Уложении о наказаниях уголовных и исправительных z 1885 r. і w Уголовном уложении ${ }^{25}$ z 1903 r. Akty te zawierały definicję osoby urzędowej (jako podmiotu odpowiedzialności), przewidywały mniejszą kazuistykę przestępstw, w tym związanych z łapownictwem ${ }^{26}$. Kolejne lata carskich rządów nie przyniosły jednak widocznych efektów w zakresie ograniczania zjawiska w Rosji.

W analizowanym okresie posługiwano się przede wszystkim pojęciem „łapownictwo", ale w 1913 r. rosyjski prawnik A. J. Estrin używał też określenia „korupcja”, przez które rozumiał zarówno niektóre czyny o charakterze administracyjnym, jak i niektóre czyny o charakterze karnoprawnym ${ }^{27}$.

\section{Prawo rosyjskie wobec łapownictwa w latach 1918-1991}

Rosja wyczerpana wojną i rewolucją była w słabej kondycji gospodarczej. W kraju nastąpił wzrost nielegalnego handlu, spekulacji i przestępstw przeciwko mieniu. Trudna sytuacja kraju sprzyjała więc wykorzystywaniu przez urzędników zajmowanych stanowisk do celu realizacji własnych interesów. To właśnie w tym okresie, jak podaje A. J. Jepichin ${ }^{28}$, oprócz tradycyjnych form łapówki pojawiły się „łapówki ukryte”. Przybierały one zawoalowaną postać, np.

${ }^{22}$ А. И. Мизерий, op. cit.

${ }^{23}$ Ibidem.

${ }^{24}$ А. И. Годунов, ор. cit., s. 330.

${ }^{25}$ W Polsce przyjęta nazwa aktu brzmi: „Kodeks Tagancewa”.

${ }^{26}$ А. И. Мизерий, оp. cit.

27 А. Я. Эстрин, Взяточничество, Петербурский университет, Кружок уголовного права, Труды, Санкт-Петербург 1913 zа: Криминология, ред. А. И. Долгова, Москва 2007, s. 712.

${ }^{28}$ А. Ю. Епихин, Борьба с взяточничеством и коррупиией в России в начале 20-х годов: уроки и опыт, [w:] Коррупиия и борьба с ней, ред. В. В. Астанин, А. И. Долгова, Н. Н. Даниленко, О. А. Евланова, Е. М. Юцкова, Москва 2000, s. 189. 
nagród oraz tzw. „opłat manipulacyjnych” czy „opłat organizacyjnych” na rzecz skorumpowanych urzędników. Nastąpił rozwój kumoterstwa, handel informacjami o zdolnościach kredytowych osób fizycznych i prawnych, organizowanie prywatnych przedsiębiorstw przez urzędników, którzy wykorzystywali do tego celu swoje stanowiska itd. ${ }^{29}$ Zatem praktycznie zjawisko przekroczyło granice łapownictwa. Pod pojęciem rozwijającego się wówczas łapownictwa należało więc rozumieć już zdecydowanie szerszy (niż wręczenie czy przyjęcie łapówki) katalog nielegalnych zachowań.

Dlatego też nowa władza podeszła zdecydowanie do tego problemu. W Dekrecie Rady Komisarzy Ludowych (SNK) z 08.05.1918 r. „О взяточничестве” przewidziano szeroki krąg osób podlegających odpowiedzialności: sprawców, podżegaczy i pomocników do przestępstw ${ }^{30}$. Przepisy skierowane były głównie przeciwko byłym właścicielom banków i fabryk, którzy zdaniem A. W. Kurakina $^{31}$ dążyli do ekonomicznej kontrrewolucji. Zatem regulacje te, w założeniu, nie służyły ograniczaniu zjawiska łapownictwa, ale zwalczaniu prawdziwych, potencjalnych lub domniemanych wrogów politycznych.

$\mathrm{W}$ analizowanym okresie istotne znaczenie dla zwalczania łapownictwa stanowiły rosyjskie kodeksy karne z 1922 r., 1926 r. i 1960 r. Uzupełniały je też inne akty prawne, głównie o charakterze administracyjnym i cywilnym.

Kodeks karny z $1922 \mathrm{r}^{32}$ odpowiedzialność za łapownictwo przewidywał $\mathrm{w}$ art. 114. Na jego podstawie odpowiedzialności podlegała osoba będąca na państwowej, związkowej lub społecznej służbie, która osobiście lub przez pośredników przyjęła jakąkolwiek łapówkę za podjęcie lub niepodjęcie w interesach osoby wręczającej jakichkolwiek czynności wchodzących w zakres obowiązków służbowych tej jednostki. Czyn zagrożony był karą pozbawienia wolności na okres do lat 5 lub fakultatywnie karą konfiskaty mienia. W świetle tego przepisu karana była też osoba pośrednicząca przy przyjmowaniu łapówki oraz osoba ukrywająca taki czyn. Groziła za to kara pozbawienia wolności na okres do 2 lat lub fakultatywnie kara konfiskaty mienia. Karze surowszej (karze pozbawienia wolności w warunkach surowej izolacji na okres nie krótszy niż 3 lata do kary śmierci włącznie i konfiskacie mienia) podlegała osoba przyjmująca łapówkę w okolicznościach obciążających. Stanowiły je: posiadanie przez osobę urzędową przyjmującą łapówkę szczególnych uprawnień lub naruszenie obowiązków służby, lub dopuszczenie się uzyskania łapówki drogą wymuszenia bądź szantażu.

${ }^{29}$ Ibidem, s. 189-190.

30 А. В. Куракин, Предупреждение и пресечение коррупции в период формирования и функиионирования административно-командной системы (1917-1991), „Следователь” 2003, nr 3, s. 25.

${ }^{31}$ Ibidem, s. 26.

32 Уголовный кодекс Р.С.Ф.С.Р. в редакции 1922 года http://www.library.ru/ help/docs/ n10349/ yk1922.txt 
W art. 114 k.k. z 1922 r. uregulowano także odpowiedzialność osoby wręczającej łapówkę. Za taki czyn przewidziano karę pozbawienia wolności do lat 3. W świetle tego przepisu natomiast nie podlegała karze jednostka, która zawiadomiła o wymuszeniu łapówki lub współpracowała przy wykryciu przestępstwa łapownictwa. Należy zauważyć, że ustawodawca nie sprecyzował pojęcia „osoba będąca na państwowej, związkowej lub społecznej służbie”.

Omawiane przestępstwo zawarte było w części II kodeksu karnego pt.: „Przestępstwa urzędnicze (służbowe)”. Można w niej wskazać także inne czyny o charakterze łapowniczym, takie jak: prowokacja łapówki (art. 115), nadużycie władzy (art. 105), wydawanie orzeczeń przez sędziów w celu osiągnięcia korzyści majątkowej (art. 111).

$\mathrm{W}$ analizowanym okresie, w związku z realizacją NEP-u zlikwidowano ograniczenia $\mathrm{w}$ handlu i przemyśle, do udziału w gospodarce dopuszczono przedsiębiorców prywatnych ${ }^{33}$. Stąd też w obawie przed wzrostem łapownictwa podpisane zostało w dniu 0.1.09.1922 r. Postanowienie Rady Pracy i Obrony przewidujące wiele środków stanowiących reakcję na zjawisko. W celu ich realizacji w dniu 24.091922 r. powstała komisja do walki z łapownictwem, na czele której stanął F. Dzierżyński. Wydał on Положение о ведомственных комиссиях по борьбе с взяточничеством. W świetle okólnika wydanego przez Ludowy Komisariat Sprawiedliwości RSFSR osoby posiadające wiedzę o przyjęciu lub wręczeniu łapówki przez inne osoby, a nie zgłaszające tego organowi ponosiły odpowiedzialność karną za pomocnictwo. Sprawy należało rozpatrywać w trybie uproszczonym, orzekać kary do 3 lat zesłania ${ }^{34}$.

W tym okresie przyjęto także kilka innych aktów prawnych zmierzających do ograniczenia zjawiska, nр.: Временные правила о службе в государственных учреждениях и предприятях z 21.121922 r., Положение об экономическом управлении Главного политического управления z 30.01 .1923 r., a także Положение о государственной гражданской службе z 1924 r. (przewidujące szereg ograniczeń, np. kontrolę dochodów osób będących na służbie państwowej). Przepisy te miały charakter administracyjny ${ }^{35}$.

W tym miejscu można postawić pytanie: czy w owym okresie kształtującego się nowego aparatu urzędniczego, rozbudowanego systemu biurokracji, jakiekolwiek prawo przeciwdziałające łapownictwu mogło być skuteczne? Należy odpowiedzieć, że nawet wysoki poziom legislacji takich przepisów, a także duża kazuistyka czynów, surowe sankcje w obliczu niewłaściwie dobranej kadry urzędniczej nie mogły przynieść rezultatów. Tak też się stało. Pomimo szerokiego frontu walki z łapownictwem, jak pisze A. I. Kirpicznikow: „korupcja przeniknęła struktury władzy radzieckiej od pierwszych minut jej rzeczywistej

\footnotetext{
${ }^{33}$ А. Ю. Епихин, op. cit., s. 188.

${ }^{34}$ А. В. Куракин, op. cit., s. 26.

${ }^{35}$ Ibidem, s. 28.
} 
władzy". Urzędnicy nowego aparatu wprowadzili stare biurokratyczne zwycza$\mathrm{je}^{36}$.

W kodeksie karnym z $1926 r{ }^{37}$ przestępstwa łapownictwa zostały umieszczone w dwóch przepisach: art. 117 (przyjęcie łapówki) i art. 118 (wręczenie łapówki).

W świetle art. 117 odpowiedzialności karnej podlegała osoba urzędowa, która osobiście lub przez pośredników przyjęła jakąkolwiek łapówkę za to, że dokonała lub nie dokonała w interesach osoby wręczającej jakiejkolwiek czynności, którą osoba urzędowa mogła lub powinna wykonać wyłącznie w ramach zajmowanego stanowiska służbowego. Zachowanie takie zagrożone było karą pozbawienia wolności do lat 2. Jeśli przyjęcie łapówki popełnione było w okolicznościach obciążających, takich jak: a) wykorzystanie odpowiedzialnego stanowiska przez osobę urzędową przyjmującą łapówkę; b) w warunkach uprzedniej karalności za łapówkę lub przy niejednokrotnym przyjęciu łapówki; c) przez wymuszenie łapówki przez osobę przyjmującą, to sprawca podlegał karze pozbawienia wolności w surowej izolacji na okres nie krótszy niż 2 lata, a nawet karze śmierci przez rozstrzelanie oraz konfiskacie mienia.

W tym miejscu należy podkreślić, że w przypisie do art. 109 k.k. (nadużycie władzy lub stanowiska służbowego) zdefiniowano pojęcie osoby urzędowej. Należało przez nie rozumieć osobę zajmującą stałe lub czasowe stanowisko $\mathrm{w}$ państwowym (radzieckim) organie, instytucji, a także w organizacji lub związku, na które nałożone są prawem określone obowiązki, prawa i pełnomocnictwa do zarządzania, a także do wykonywania administracyjnych lub innych ogólnopaństwowych zadań.

W świetle art. 118 odpowiedzialności karnej podlegała osoba wręczająca łapówkę lub pośrednicząca w łapownictwie. Czyn zagrożony był karą pozbawienia wolności do 5 lat. W przypisie do tego przepisu wskazano, że osoby ponoszące odpowiedzialność na podstawie artykułu 118 podlegają uwolnieniu od odpowiedzialności karnej w sytuacjach: a) jeśli wobec nich nastąpiło wymuszenie łapówki, b) jeśli po wręczeniu łapówki natychmiast dobrowolnie poinformowały o przestępstwie.

Przestępstwa te zawarto w części III kodeksu karnego pt.: „Przestępstwa urzędnicze (służbowe)”. Można w niej wskazać także kilka innych przepisów zmierzających do ograniczania łapownictwa, takich jak: prowokacja łapówki (art. 119), nadużycie władzy (art. 109), wydawanie niepraworządnych orzeczeń przez sędziów w celu osiągnięcia korzyści majątkowej (art. 111), fałszerstwo urzędnicze (art. 120).

${ }^{36}$ Я. И. Кирпичников, op. cit., s. 59

37 Уголовный кодекс Р.С.Ф.С.Р. в редакиии 1926 года (с изм. и доп., внесенными Постановлениями ЦИК СССР от 19.02.1926 - С3, 1926, N 9, ст. 71; от 05.03.1926 - С3, 1926, No 15, ст. 106) http://www.soldat.ru/files/3/22/32/605.html 
Należy stwierdzić, że oba kodeksy zawierały podobne, a nawet analogiczne uregulowania w zakresie zarówno przyjęcia, jak i wręczenia łapówki, kryminalizacji pośrednictwa i ukrywania łapownictwa. Przewidywały też inne czyny o takim charakterze. Za wymienione przestępstwa ustawodawca przewidział dosyć wysokie kary finansowe, izolacyjne, a nawet eliminacyjną. Odmiennie ujął podmiot odpowiedzialności karnej, bowiem w k.k. z 1922 r. za taki uznał „jednostkę będącą na służbie państwowej, związkowej lub społecznej”, a w k.k. z 1926 r. - „osobę urzędową".

W tym miejscu należy zauważyć, że po raz pierwszy w historii Rosji (ZSRR) funkcjonowanie administracyjno-karnego systemu regulacji wobec łapownictwa przyniosło efekty. Odnotowano bowiem, jak podaje A.W. Kurakin, jego spadek, co w efekcie przyczyniło się do zniesienia w 1927 r. kary śmierci za przyjęcie łapówki w okolicznościach obciążających. Wpłynęło to z pewnością, jego zdaniem, na powstanie bardziej ukrytych form tego zjawiska. W znacznym stopniu bowiem, w latach trzydziestych, charakteryzowały go głównie nadużycia stanowisk służbowych w celach politycznych i osiągania korzyści majątkowych $^{38}$.

Nawet okres II wojny nie spowodował spadku łapownictwa w ZSRR, czego wyrazem było uchwalenie aktu prawnego z 27.121944 r. Об усилению борьбы с взяточничеством, który pozwolił na większą swobodę organom ochrony porządku prawnego do pociągania do odpowiedzialności karnej jego sprawców. Przepisy tego aktu znalazły też odbicie w tzw. planie antykorupcyjnym z 1947 r. opracowanym przez prokuraturę, ministerstwo sprawiedliwości i milicję; wskazywał on na potrzebę prowadzenia działalności analitycznej zjawiska, walki z nim, zmian w ustawodawstwie. Jego realizacja spowodowała wzrost skazań za przestępstwa związane $\mathrm{z}$ lapownictwem ${ }^{39}$. Jednakże wysiłki podejmowane $\mathrm{w}$ dłuższej perspektywie $\mathrm{w}$ celu stworzenia efektywnego prawa wobec takich czynów, nie wpłynęły na zmniejszenie skali zjawiska.

W kodeksie karnym RSFSR z 1960 r. ${ }^{40}$ przestępstwa łapownictwa zawarte zostały w części VII zatytułowanej „Przestępstwa urzędnicze”.

Przyjęcie łapówki uregulowano w art. 173 k.k. W świetle tego przepisu zjawisko to polegało na przyjęciu przez osoby urzędowe lub przez pośredników jakiejkolwiek łapówki za podjęcie lub niepodjęcie w interesach osoby wręczającej jakiejkolwiek czynności, którą osoba urzędowa mogła lub powinna dokonać wyłącznie w ramach stanowiska służbowego. Przestępstwo zagrożone było karą pozbawienia wolności na okres do 5 lat. Czyny te, popełnione przez osobę urzędową zajmującą odpowiedzialne stanowisko lub przez osobę uprzednio ka-

${ }^{38}$ А. В. Куракин, ор. cit., s. $28-29$.

${ }^{39}$ Ibidem, s. 29.

40 Уголовный кодекс РСФСР - Закон РСФСР от 27 октября 1960 года «Об утверждении Уголовного кодекса РСФСР», Ведомости Верховного Совета РСФСР от 31 октября 1960 года. № 40, ст. 591, http://dic.academic.ru/dic.nsf./ruwiki/692889 
raną za łapownictwo lub przez tę, która przyjęła łapówkę niejednorazowo lub w związku z wymuszeniem, podlegały karze pozbawienia wolności na okres od 5 do 10 lat i fakultatywnie karze konfiskaty mienia.

W 1962 r. nastąpiły zmiany w redakcji tego przepisu, gdyż odpowiedzialność za łapownictwo została ukształtowana przez Ukaz Prezydium Rady Najwyższej ZSRR z 20.02.1962 r. Об усилению уголовной ответственности за взяточничество, który przewidywał surowszą odpowiedzialność za przyjęcie łapówki. Przepisy tego ukazu zostały włączone do artykułów 173, 174, 174 ${ }^{1}$ k.k. Znowelizowane rozwiązania za przyjęcie łapówki przewidywały karę pozbawienia wolności na okres od 3 do 10 lat i karę konfiskaty mienia. Czynności podjęte przez osobę urzędową zajmującą odpowiedzialne stanowisko lub uprzednio karaną za łapownictwo albo niejednorazowe przyjęcie łapówki lub związane z jej wymuszeniem zagrożone były karą pozbawienia wolności od 8 do 15 lat i karą konfiskaty mienia oraz fakultatywnie zesłaniu po odbyciu kary pozbawienia wolności na okres od 2 do 5 lat. Jeśli natomiast zostały popełnione w okolicznościach szczególnie obciążających - karą śmierci i karą konfiskaty mienia.

Pojęcie osoby urzędowej ustawodawca radziecki określił w przypisie do art. 170 k.k. (nadużycie władzy lub stanowiska służbowego). Uczynił to jednak dopiero Ukazem Prezydium Rady Najwyższej RSFSR z 3.12.1982 r. ${ }^{41}$ Rozumiał przez nie osoby stale lub czasowo pełniące funkcje przedstawicieli władzy, a także stale lub czasowo zajmujące stanowiska w państwowych lub społecznych instytucjach bądź organizacjach związanych $\mathrm{z}$ wypełnianiem organizacyjno-zarządzających, kierowniczych albo organizacyjnych obowiązków lub też wypełniające takie obowiązki w wymienionych instytucjach i organizacjach na podstawie specjalnego pełnomocnictwa.

W świetle analizowanego art. 173 k.k. łapówka mogła być przyjęta w pieniądzu, mieniu lub w formie innej korzyści o charakterze majątkowym (np. opłata wyjazdu do kurortu, opłata mieszkania). Korzyści o charakterze niemajątkowym nie miały cech przedmiotu łapówki. Przyjęto, że łapówką było przyjęcie wynagrodzenia we wspomnianych formach zarówno za działanie, jak i za zaniechanie osoby urzędowej. Również czas przyjęcia nie był istotny, czy przed wykonaniem czynności przez osobę urzędową, czy też później ${ }^{42}$.

Już w latach sześćdziesiątych rozumiano, że ze względu na różnorodność łapówek i metod ich przyjmowania nie sposób było uregulować prawnie wszystkich zachowań z tym związanych. Kryminalizowano, penalizowano i karano sądownie tylko jawne formy łapownictwa (czyli przyjęcie konkretnego przedmiotu), a nie form zawoalowanych, jak np.: premii, nagród mających podłoże korupcyjne. W świetle ówczesnego prawa zachowanie powyższe kwalifikowane

${ }^{41}$ Ведомости Верховного Совета РСФСР 1982, Нр 49, ст. 1821.

42 Комментарий к уголовному кодексу РСФСР 1960, ред. Г. П. Тихонова, А. А. Большаков, Ленинград 1962, s. 314. 
było jako łapownictwo tylko wtedy, gdy owe korzyści uzyskane zostały niezgodnie z prawem (np. nie wykonano pracy za przyznaną nagrodę). ${ }^{43}$

$\mathrm{Na}$ tym etapie rozważań analizie należy poddać kolejne części składowe przepisu. Za interesy osoby wręczającej łapówkę uznawano nie tylko jej interesy osobiste, ale także interesy innych osób i instytucji ${ }^{44}$. Przez wykorzystanie stanowiska służbowego przez osobę urzędową rozumiano zachowania podejmowane w ramach jej praw i obowiązków. Jako wykorzystanie stanowiska traktowano również wpływanie przez osobę urzędową na podwładnych w celu wykonania określonego przez nią zadania ${ }^{45}$. Pośrednictwo innych osób polegało na udzieleniu pomocy w zawarciu umowy, osiągnięciu porozumienia między osobą wręczającą a przyjmującą do realizacji tę umowę. Mogło to przejawiać się w organizacji spotkań, tworzeniu warunków sprzyjających sytuacji, w której miało nastąpić przekazanie łapówki ${ }^{46}$.

Należy zauważyć, że ustawodawca nie zdefiniował pojęcia „odpowiedzialne stanowisko”. Uznał, jak podają prawnicy, że należało je interpretować w odniesieniu do konkretnych okoliczności sprawy (np. zakresu obowiązków urzędnika, zajmowanego stanowiska) ${ }^{47}$. Z kolei uprzednią karalność stanowiło wcześniejsze skazanie osoby za przyjęcie, wręczenie łapówki, pośredniczenie przy łapownictwie ${ }^{48}$, a niejednorazowe przyjęcie łapówki było przyjęciem jej co najmniej dwa razy lub od dwóch lub więcej osób albo dwóch łapówek od jednej osoby. Wymuszenie łapówki natomiast oznaczało postawienie wymagań osobie dającej łapówkę pod groźbą dokonania czynności niezgodnych z jej interesa$\mathrm{mi}^{49}$

Przestępstwo przyjęcia łapówki z art. 173 k.k. traktowano jako bardzo niebezpieczne przestępstwo urzędnicze. Uznano bowiem, że narusza ono autorytet władzy państwowej, przekonuje o możliwości osiągania określonych celów drogą podkupu urzędników, wykazuje powiązania z innymi przestępstwami: spekulacją czy defraudacją mienia socjalistycznego ${ }^{50}$.

Wręczenie łapówki uregulowano w art. 174 k.k. Przedmiotem czynności wykonawczej uczyniono zarówno wręczenie, jak i pośrednictwo przy łapownictwie. Przestępstwo zagrożono karą pozbawienia wolności do lat 3 lub karą pracy poprawczej na okres do jednego roku. Surowiej (karą pozbawienia wolności do lat 5) karano wręczenie łapówki lub pośrednictwo przy łapownictwie, lub niejednorazowe popełnienie tego przestępstwa bądź popełnienie przez oso-

\footnotetext{
${ }^{43}$ Комментарий к Уголовному кодексу РСФСР, ред. О. В. Грачев, Москва 1992, s. 446.

${ }^{44}$ Комментарий..., ор. cit., s. 314.

${ }^{45}$ Комментарий к Уголовному..., s. 446.

${ }^{46}$ Комментарий..., s. 315.

${ }^{47}$ Ibidem, s. 315.

${ }^{48}$ Комментарий к Уголовному..., s. 449.

${ }^{49}$ Ibidem, s. 315.

${ }^{50}$ Комментарий к Уголовному..., s. 445.
} 
bę uprzednio karaną za łapownictwo. W przypisie do tego artykułu zapisano warunki uwolnienia od odpowiedzialności karnej osoby wręczającej łapówkę. Stanowiły je: wymuszenie łapówki od osoby wręczającej lub dobrowolne złożenie zawiadomienia o popełnionym przestępstwie.

Po zmianach wprowadzonych ukazem z 1962 r. wręczenie łapówki z art. 174 zagrożono karą pozbawienia wolności od 3 do 8 lat. A za niejednorazowe wręczenie łapówki lub popełnienie przez osobę uprzednio karaną za łapownictwo przewidziano karę pozbawienia wolności od 7 do 15 lat, fakultatywną karę konfiskaty mienia, fakultatywne zesłanie po uprzednim odbyciu kary pozbawienia wolności na okres od 2 do 5 lat.

Warto podkreślić, że wręczenie łapówki nie było i nie jest przestępstwem urzędniczym, ale związane jest w sposób nierozerwalny z osobą urzędową. Dlatego też zostało umieszczone w tej części kodeksu.

Przestępstwo to polegało na przekazaniu osobie urzędowej lub przez pośrednika materialnych przedmiotów lub korzyści majątkowej za podjęcie lub niepodjęcie czynności w interesach osoby wręczającej, którą osoba urzędowa musiała lub mogła zrealizować z wykorzystaniem swego stanowiska służbowego ${ }^{51}$.

Pojęcie wymuszenia łapówki zostało omówione wcześniej, wobec czego zostanie tu pominięte. Natomiast przez dobrowolne poinformowanie o popełnionym przestępstwie wręczenia łapówki należało rozumieć swobodną, dobrowolną inicjatywę ujawnienia informacji o przestępstwie. Zawiadomienie należo złożyć odpowiednim organom zajmującym się ściganiem łapownictwa ${ }^{52}$.

W związku z wejściem w życie ukazu z 1962 r. przepis art. 174 został podzielony na dwa artykuły: art. 174 (omówiony) i art. 174'. Przewidziano w nim przestępstwo pośrednictwa przy łapownictwie zagrożone karą pozbawienia wolności od 2 do 8 lat. Ponadto przyjęto, że pośrednictwo przy łapownictwie dokonane niejednorazowo lub popełnione przez osoby uprzednio karane za łapownictwo lub z wykorzystaniem swego stanowiska służbowego podlegało karze pozbawienia wolności na czas od 7 do 15 lat, karze konfiskaty mienia i fakultatywnie zesłaniu po odbyciu kary pozbawienia wolności na okres od 2 do 5 lat. Oddzielna kryminalizacja pośrednictwa wynikała $\mathrm{z}$ faktu uznania tego zachowania jako istotnego elementu między biorcą i dawcą łapówki.

Ponadto w części kodeksu penalizujacej omówione przestępstwa można wskazać jeszcze kilka czynów o charakterze łapowniczym, takich jak: nadużycie władzy lub stanowiska służbowego (art. 170) i fałszerstwo urzędnicze (art. 175).

\footnotetext{
${ }^{51}$ Ibidem, s. 452.

${ }^{52}$ Комментарий..., s. 316.
} 
Należy stwierdzić, że w kodeksie karnym z 1960 r. dokonano wręcz kazuistycznej penalizacji łapownictwa i przewidziano za nie wysokie kary o charakterze finansowym i izolacyjnym.

Jednak od początku 1960 r., zdaniem A.W. Kurakina, w rezultacie nieefektywnej kontroli społecznej, ignorowania przez sądy łapownictwa, niereagowania na przyczyny zjawiska, osiągnęło ono poważne rozmiary, zwłaszcza w aparacie państwowym. Niedostatki w sferze ekonomicznej, deficyt towarów, niskie zarobki urzędników sprzyjały tzw. korupcji urzędniczej. Paradoks polegał na tym, że przestępstwa łapownictwa ścigali ci, którzy je popełniali. Tworzone w latach osiemdziesiątych kodeksy etyki urzędniczej w warunkach rodzącej się gospodarki rynkowej, pojawienie się sektora prywatnego, na nic się zdały. Rola urzędników ponownie zaczęła rosnąćs $c^{53}$.

Walkę z łapownictwem w socjalistycznej Rosji celnie scharakteryzował A. W. Gyske ${ }^{54}$. Zwrócił on uwagę, że przez lata władza radziecka nie używała pojęcia korupcja, nie potwierdzając $w$ ten sposób istnienia problemu. Posługiwała się określeniami: „łapownictwo”, „nadużywanie stanowiska”, „pobłażliwość". W sposób przedziwny, wręcz naiwny, wyjaśniała przyczyny tego zjawiska w ZSRR, a mianowicie „jako zjawiska zrodzonego w warunkach społeczeństwa eksploatacyjnego"55. Jego zdaniem, zwalczanie problemu w państwie radzieckim było bardzo trudne, gdyż udział w tym brali skorumpowani urzędnicy. Prowadziło to „do przekształcenia walki z korupcją w walkę z konkurentami na rynku usług korupcyjnych"56.

\section{Prawo rosyjskie wobec korupcji w latach 1992-2009}

Po rozpadzie ZSRR, w Rosji pierwszą regulację o charakterze antykorupcyjnym stanowił Ukaz O борьбе с коррупиией в системе государственной службы ${ }^{57}$ wydany w 1992 r. przez Prezydenta Federacji Rosyjskiej. Na jego podstawie funkcjonariusze aparatu państwowego nie mogli prowadzić działalności gospodarczej, udzielać płatnej pomocy przedsiębiorcom przy wykorzystaniu swego stanowiska służbowego, uczestniczyć w spółkach akcyjnych lub z ograniczoną odpowiedzialnością. Zostali też zobowiązani do składania oświadczeń majątkowych. Kolejne rozwiązania antykorupcyjne zostały przewidziane np. w ustawie z 1995 r. Об основах государственной службы Российской

${ }^{53}$ А. В. Куракин, op. cit., s.30.

${ }^{54}$ А. В. Гыскэ, Современная российская преступность и проблемь безопасности общества. Политический анализ, Москва 2000, s. 138.

${ }_{55}$ А. В. Гыскэ powołuje się na niejawne pismo Komitetu Centralnego KPSS „О усилению борьбы с взяточничеством и разворовыванием народного добра” z 29.03.1962 r.

${ }^{56}$ А. В. Гыскэ, ор. cit., s. 138

57 Указ Президента ФР от 4.04.1992 г. О борьбе с коррупиией в системе государственной службы, http://www.businesspravo.ru/Docum/DocumShow_DocumID_40585.html 
Федерации сzy w Ukazie Prezydenta z 1996 r. О мерах по укреплению дисииплины в системе государственной службы. Wprowadziły one nowe ograniczenia dla urzędników państwowych. Przepisy antykorupcyjne zawierał też przyjęty w $1996 \mathrm{r}$. kodeks cywilny ${ }^{58}$, zabraniający przyjmowania przez wiele podmiotów, w związku z wykonywaniem obowiązków służbowych, prezentów w wysokości przekraczającej trzy tysiące rubli. Od 2008 r. zakaz ten nie dotyczy podarunków uzyskanych głównie w związku z przedsięwzięciami dyplomatycznymi i delegacjami służbowymi urzędników.

Jednakże najważniejszy akt prawny w zakresie korupcji - kodeks karny Federacji Rosyjskiej (k.k. FR) ${ }^{59}$ został uchwalony w 1996 r. Zawiera on następujące przestępstwa korupcyjne: uniemożliwianie realizacji praw wyborczych lub pracy komisji wyborczych (art. 141), fałszowanie dokumentów wyborczych, dokumentów referendum (art. 142), niezgodne z prawem wejście w posiadanie i rozgłaszanie informacji stanowiących tajemnicę handlową, podatkową lub bankową (art. 183) ${ }^{60}$, przekupstwo uczestników i organizatorów profesjonalnych zawodów sportowych i widowiskowych konkursów (art. 184), komercyjne (handlowe) przekupstwo (art. 204), przyjęcie łapówki (art. 290), wręczenie łapówki (art. 291), prowokacja łapówki lub przekupstwo (komercyjne) handlowe (art. 304), przekupstwo świadka, pokrzywdzonego, biegłego lub wymuszenie złożenia przez nich zeznania lub uniknięcie złożenia przez nich zeznania, lub też dokonanie nieprawidłowego tłumaczenia przez tłumacza (art. 309). Oprócz wymienionych przestępstw, rosyjski kodeks karny przewiduje w ponad dwudziestu artykułach odpowiedzialność za przestępstwa popełnione w celu osiągnięcia korzyści majątkowej ${ }^{61}$, dokonane przy wykorzystaniu stanowiska służbowego. Czyny te także mają charakter przestępstw korupcyjnych. Taki zakres przestępstw wyczerpuje najbardziej rozpowszechnione w Rosji przejawy korupcji urzędniczej, sportowej, gospodarczej i wyborczej.

W 2001 r. został uchwalony kolejny akt prawny o charakterze antykorupcyjnym - kodeks Federacji Rosyjskiej o administracyjnych naruszeniach prawa ${ }^{62}$. W art. 5.16 przewiduje on penalizację przekupstwa wyborców, uczestników referendum lub prowadzenia działalności dobroczynnej $\mathrm{w}$ okresie kampanii wyborczej, kampanii referendalnej z naruszeniem ustawodawstwa o wyborach i referendach.

${ }^{58}$ Grażdanskij kodeks (czast' wtoraja ot 26.01 .1996 g., $\mathrm{Nr}$ 11-FZ), http://www.garant.ru/ main/10064072-032.htm\#par2961

59 Уголовный кодекс Российской Федерации от 13.06.1996. Kodeks ten został przyjęty przez Dumę Państwową 24.05.1996 r., zaakceptowany przez Radę Federacji 5.061996 r., a podpisany przez Prezydenta FR 13.06.1996 r. Wszedł w życie 1 stycznia 1997 r.

${ }^{60} \mathrm{~W}$ trzech wyżej wymienionych przestępstwach przekupstwo jest jednym z kilku sposobów popełnienia przestępstwa.

${ }_{61}^{6}$ Dane takie podaje: Ю. А. Коков, Как победить коррупцию, „Следователь” 2008, nr 10 , s. 33 .

${ }^{62}$ Кодекс ФР об административных правонарущениях от 30.12.2001 г., N 195-Ф3, http:// www.lawmix.ru/zak.php 
Pomimo szerokiego zakresu ujęcia czynów o charakterze korupcyjnym nadal poza sferą regulacji prawnej pozostają następujące zachowania: lobbing, faworyzowanie, protekcjonizm, nepotyzm, stosowanie ulg i zwolnień wobec wybranych osób ${ }^{63}$.

Należy zauważyć, że w „Koncepcji narodowego bezpieczeństwa Federacji Rosyjskiej”"64 z 1997 r. zaliczono korupcję wraz z przestępczością zorganizowaną i terroryzmem do najpoważniejszych zagrożeń bezpieczeństwa narodowego. Jednak w kolejnych latach nie miało to wpływu na ograniczanie zjawiska. $\mathrm{Na}$ problem ponownie zwrócił uwagę 31.07.2008 r. rosyjski prezydent D. Miedwiediew, który podpisał „Narodowy plan przeciwdziałania korupcji” ${ }^{65}$, przewidujący szereg zmian prawnych i organizacyjnych w tym zakresie. Jego realizacja miała doprowadzić do uchwalenia ustawy „o przeciwdziałaniu korupcji” i dokonania zmian w około 25 innych aktach prawnych ${ }^{66}$. Był to zwiastun wprowadzenia efektywnych rozwiązań w dziedzinie przeciwdziałania i zwalczania korupcji w Rosji.

I rzeczywiście, w bardzo szybkim tempie, bo już w grudniu 2008 r. uchwalono trzy ustawy antykorupсуjne: Федеральный закон Российской Федерации oт 25 декабря 2008 2. N 273-Ф3 „О противодействии коррупиии”, Федеральный закон Российской Федерачии от 25 декабря 2008 г. N 274-ФЗ „О внесении изменений в отдельные законодательные акты Российской Федерации в связи с принятием Федерального закона "О противодействии коррупиии»"68 і Фдеральный закон Российской Федерации от 25 декабря 2008 г. N 280-Ф3 „О внесении изменений в отдельные законодательные акты Российской Федерации в связи с ратификацией Конвенции Организации Объединенных Начий против коррупиии от 31 октября 2003 года и Конвенции об уголовной ответственности за коррупиию от 27 января 1999 года и принятием Федерального закона «О противодействии коррупиии»"'69. Na ich podstawie dokonano zmian w ponad 15 aktach prawnych ( $\mathrm{w}$ tym we wspomnianym kodeksie cywilnym i kodeksie karnym ${ }^{70}$ ), dotyczących przede wszystkim sędziów, funkcjonariuszy milicji, funkcjona-

${ }_{63}$ Zob. В. В. Лунеев, Преступность ХХ века. Мировые, региональные и российские тендениии, Москва 2005, s. 521.

${ }^{64}$ Концепциия национальной безопасности Российской Федерации от 17.12.1997 г., (przyjęta Ukazem Prezydenta FR Nr 1300), Собрание законодательства ФР 2000, Нр 2, ст. 170.

${ }^{65}$ Национальный план противодействия коррупции, www. kremlin.ru/text/docs/2008/ 07/204857.shtml

${ }^{66}$ Niemal natychmiast poddano go krytyce. Zob. Н. Егорова, О рациональном плане противодействия коррупиии, „Государство и право” 2008, nr 6, s. 89 i n.

${ }^{67} \mathrm{http}: / /$ www.rg.ru/2008/12/30/korrupcia-fz-dok.html

${ }^{68} \mathrm{http}: / /$ www.rg.ru/2008/12/30/korrupcia-akty-dok.html

${ }^{69} \mathrm{http}: / /$ www.rg.ru/2008/12/30/akty-konvencii-dok.html

${ }^{70} \mathrm{Zmiany}$ wprowadzone przez te ustawy w kodeksie karnym dotyczą instytucji, konfiskaty mienia oraz podniesienia zagrożenia karnego o jeden rok za popełnienie przestępstwa $\mathrm{z}$ art. 201 pkt 1 (nadużycie uprawnień) i art. 204 pkt 1 (przekupstwo komercyjne). 
riuszy FSB, funkcjonariuszy celnych, pracowników Izby Rachunkowej i Banku Centralnego; nałożono na nich szereg ograniczeń, obowiązków i zakazów, głównie w zakresie otrzymywania wynagrodzenia od osób fizycznych i prawnych, przyjmowania prezentów, składania oświadczeń majątkowych.

W tym miejscu można postawić pytanie: czy w związku z kilkuwiekową regulacją omawianego zjawiska ukształtował się w Rosji określony model ustawodawstwa antykorupcyjnego? W celu udzielenia odpowiedzi na to pytanie należy poddać ocenie kilka elementów przedstawionej powyżej prawnej regulacji problemu w dziejach tego kraju: siatkę pojęciową, zakres kryminalizacji czynów, wysokość zagrożenia karnego, źródła prawa i ich charakter, a także stosowanie prawa w praktyce.

Zważywszy, że kształtowanie się znaczenia i zakresu podstawowych pojęć dotyczących korupcji trwało kilka wieków, zrozumiałe jest, iż w okresie tym przyjmowano różne określenia na zachowania korupcyjne. Jak można zauważyć, podstawowym, stale obecnym pojęciem prawnym było „łapownictwo”, a „korupcja” - stosunkowo od niedawna - pojęciem o charakterze kryminologicznym ${ }^{71}$. Charakteru prawnego nabrało ono dopiero od 2008 r. Stworzenie legalnej definicji korupcji w założeniu miało określić i uporządkować znaczenie tego słowa. Jednak z praktycznego punktu widzenia niczego nie zmieniło. Pod pojęciem rozumie się bowiem zakres wielu czynów od dawna uregulowanych w kodeksie karnym.

Analiza ustawodawstwa obowiązującego w omawianym okresie pozwala stwierdzić, że najczęściej kryminalizowanym przez prawo czynem było przyjęcie łapówki. Z upływem lat zakres kryminalizacji uległ rozszerzeniu m.in. o wręczenie łapówki, pośrednictwo przy łapownictwie, wymuszanie łapówki, niezawiadomienie o łapownictwie innej osoby. Należy zauważyć, że nadal część zachowań o charakterze korupcyjnym nie została w prawie uregulowana. Uwagę zwraca rodzaj i wysokość kar przewidzianych za łapownictwo. Stanowią je kary zarówno o charakterze majątkowym, izolacyjnym, jak i eliminacyjnym. Można więc stwierdzić, że ewolucja następowała w kierunku zwiększenia represyjności prawa wobec zachowań korupcyjnych. Zatem prawo było surowe, ale czy skuteczne, skoro przez ponad siedem wieków nie udało się zjawiska wyeliminować, czy chociażby ograniczyć.

Źródła rozwiązań antykorupcyjnych stanowiły akty prawa wydawane przez władców, przywódców państwa, Sąd Najwyższy i parlament. Były to w szczególności ukazy, postanowienia, ustawy. Miały różną rangę i różnorodny charakter. Obowiązywały głównie w sferze prawa administracyjnego, cywilnego i karne-

${ }^{71}$ Zob. m.in.: С. В. Максимов, В. А. Ванцев, Коррупционная преступность, [w:] Криминология, ред. В. Н. Кудрявцев, В. Е. Эминов, Москва 2005, s. 385; А. И. Долгова, Коррупционная преступность, [w:] Криминология, ред. А. И. Долгова, Москва 2007, s. 708; Б. В. Волженкин, Коррупция, Санкт-Петербург 1998, s. 8. 
go. Tak szeroki zakres oddziaływania prawa nie przekładał się niestety na praktykę ścigania zachowań korupcyjnych. W warunkach radzieckich i rosyjskich trudno jest bowiem karać wysokich urzędników, funkcjonariuszy organów ścigania i wymiaru sprawiedliwości, polityków czy biznesmenów.

Krótka analiza powyższych elementów wielowiekowego ustawodawstwa pozwala zatem wysunąć wniosek, że do końca 2008 r., pomimo restrykcyjnego stosunku do korupcji, nie udało się w Rosji stworzyć systemu rozwiązań prawnych. Nie ukształtował się efektywny model regulacji antykorupcyjnych. Dopiero te wprowadzone w 2009 r., wydaje się, że stanowią uporządkowany, rozbudowany system. Nie przesądza to, że stworzono skuteczny model, bowiem pomimo szerokiego ujęcia przyjętych rozwiązań już pojawiają się głosy krytyczne. Dotyczą one m.in. zakresu podmiotów zobowiązanych do ujawniania dochodów (brak tego obowiązku wobec najwyższych przedstawicieli władzy: członków Rady Federacji, Dumy Państwowej, Prezydenta Federacji Rosyjskiej, ministrów rządu), czy kosmetycznych zmian w kodeksie karnym ${ }^{72}$. Zupełność i celowość przyjętych rozwiązań zweryfikuje czas.

Źródeł trudności i niepowodzeń w tworzeniu systemu prawa należy doszukiwać się przede wszystkim w istocie zjawiska społecznego, jakim jest korupcja i jego złożonych przyczyn, zwłaszcza o charakterze historycznym, politycznym, ekonomicznym, społecznym oraz organizacyjnym. Trzeba bowiem pamiętać, że w okresie carskiej Rosji przez кормление carowie sami przyczynili się do zalegalizowania korupcji urzędniczej. Wielu z nich pozwalało przez lata łapownikom zajmować wysokie stanowiska. Następny okres socjalizmu wraz ze swoimi niedoskonałościami, rozbudowanym aparatem urzędniczym i partyjnym ugruntował pozycję urzędnika oraz jego wszechwładzę decyzyjną. Nawet surowe prawo było $\mathrm{w}$ takiej sytuacji bezsilne. Okres przemian wraz z powstaniem gospodarki rynkowej, przejściem urzędników partyjnych w szeregi rządowe i biznesowe pozwoliły na powstanie oraz funkcjonowanie sieci korupcyjnych. Zatem współczesny obraz korupcji jest wynikiem zmian po 1990 r., rezultatem dysfunkcjonalności władzy, istnienia społeczno-kulturalnych tradycji wdzięczności, słabości prawa i braku świadomości prawnej społeczeństwa ${ }^{73}$. Jak widać, współczesna korupcja ma głębokie korzenie historyczne.

W warunkach radzieckich i rosyjskich szczególnie widoczny jest jeszcze jeden problem. Jak zauważa A. I. Gołosienko, branie przez urzędników łapówek jest przejawem nielojalności wobec władzy ${ }^{74}$. Należy podzielić ten pogląd, bar-

72 А. Наумов, Новое антикоррупиионное законодательство: много упущено, „Уголовное право” 2009, nr 2, s. 100-103.

${ }^{73}$ А. В. Куракин, op. cit., s. 30.

${ }^{74}$ И. А. Голосенко, Феномен „русской взятки”: очерк истории отечественной социологии чиновничества, „Журнал социологии и социальной антропологии” 1999, t. II, nr 3 (7), s. 114-116 . 
dzo aktualny w Rosji - kraju ukształtowanych i określonych przez lata relacji obywatel - państwo oraz obywatel - urząd. Dlatego trudno w takich warunkach podejrzewać urzędników rosyjskich o oddanie się służbie państwowej.

Rozważając problem korupcji w Rosji, na uwagę zasługuje fakt, że niemal każda władza podejmowała inicjatywy ustawodawcze zmierzające do ograniczenia korupcji. Jednak rola i wpływy urzędników były tak znaczące, że regulacje prawne nie osiągały swoich celów, nie były skuteczne w ograniczaniu zjawiska. W parze z prawem nie szła efektywna działalność organów ścigania i wymiaru sprawiedliwości. W takich warunkach nawet dobrze skonstruowane prawo nie mogło być skuteczne wobec postawy funkcjonariuszy państwowych i społeczeństwa, które otwarcie gardzi prawem.

Również współcześnie, wobec poważnej skali przestępczości o charakterze korupcyjnym, pomimo wprowadzonych zmian w prawie, nie należy oczekiwać znacznego ograniczenia zjawiska. Zbyt głęboko jest ono zakorzenione w świadomości społecznej. Jest to zjawisko społeczne, więc podejmowanie wobec niego wyłącznie kroków prawnych nie rozwiąże problemu. Należy zatem uświadamiać społeczeństwo o zagrożeniach wynikających z korupcji, negatywnych następstwach dla państwa, społeczeństwa i jednostki. A będzie to zadanie bardzo trudne, gdyż można pokusić się o stwierdzenie, że tak wysokiego poziomu korupcji, jak obecnie, jeszcze w historii Rosji nie notowano.

Nawiązując do tytułu publikacji, należy stwierdzić, że bilans zwalczania korupcji w Rosji jest ujemny. Państwo nadal z tego tytułu ponosi poważne straty zarówno materialne, jak i niematerialne, zarówno na arenie krajowej, jak i międzynarodowej, pomimo wielu wysiłków włożonych w stworzenie skutecznych środków prawnych służących zwalczaniu korupcji w Rosji. 